\title{
Assessment of dietary ratios of red clover and corn silages on milk production and milk quality in dairy cows
}

\author{
J. M. Moorby, ${ }^{1}$ N. M. Ellis, and D. R. Davies ${ }^{2}$ \\ Institute of Biological, Environmental and Rural Sciences, Aberystwyth University, Gogerddan, Aberystwyth, SY23 3EE, United Kingdom
}

\begin{abstract}
Twenty-four multiparous Holstein-Friesian dairy cows were used in a replicated $3 \times 3$ Latin square changeover design experiment to test the effects of changing from corn (Zea mays) silage to red clover (Trifolium pratense) silage in graded proportions on feed intakes, milk production, and whole-body $\mathrm{N}$ and $\mathrm{P}$ partitioning. Three dietary treatments with ad libitum access to 1 of 3 forage mixtures plus a standard allowance of 4 $\mathrm{kg} / \mathrm{d}$ dairy concentrates were offered. The 3 treatment forage mixtures were, on a dry matter (DM) basis: (1) R10: $90 \%$ corn silage and 10\% red clover silage, (2) R50: $50 \%$ corn silage and 50\% red clover silage, and (3) R90: $10 \%$ corn silage and $90 \%$ red clover silage. In each of 3 experimental periods, there were $21 \mathrm{~d}$ for adaptation to diets, and $7 \mathrm{~d}$ for measurements. Diet crude protein intakes increased, and starch intakes decreased, as the silage mixture changed from $90 \%$ corn to $90 \%$ red clover, although the highest forage DM intakes and milk yields were achieved on diet R50. Although milk fat yields were unaffected by diet, milk protein yields were highest with the R50 diet. Whole-body partitioning of $\mathrm{N}$ was measured in a subset of cows $(\mathrm{n}=9)$, and both the daily amount and proportion of $\mathrm{N}$ consumed that was excreted in feces and urine increased as the proportion of red clover silage in the diet increased. However, the apparent efficiency of utilization of feed $\mathrm{N}$ for milk protein production decreased from $0.33 \mathrm{~g} / \mathrm{g}$ for diet R10 to $0.25 \mathrm{~g} / \mathrm{g}$ for diet R90. The urinary excretion of purine derivatives (sum of allantoin and uric acid) tended to increase, suggesting greater flow of microbial protein from the rumen, as the proportion of red clover silage in the diet increased, and urinary creatinine excretion was affected by diet. Fecal shedding of $E$. coli was not affected by dietary treatment. In conclusion, even though microbial protein flow may have been
\end{abstract}

\footnotetext{
Received March 9, 2016.

Accepted June 20, 2016.

${ }^{1}$ Corresponding author: jon.moorby@aber.ac.uk

${ }^{2}$ Current address: Silage Solutions Ltd., Bwlch y Blaen, Pontrhydygroes, Ystrad Meurig, SY25 6DP, United Kingdom.
}

greatest from the R90 diet, optimum feed intakes and milk yields were achieved on a diet that contained a 1:1 DM mixture of corn and red clover silages.

Key words: corn silage, milk production, nitrogen balance, red clover silage

\section{INTRODUCTION}

Red clover (Trifolium pratense) is an important crop for producing high protein silage in North America and northern Europe. As a legume, its ability to fix atmospheric $\mathrm{N}$ means that no fertilizer $\mathrm{N}$ applications are required for its cultivation, and this makes it an important crop in organic or other low-input farming systems. Red clover is a relatively short-term crop $(2-3 \mathrm{yr})$, and the accumulation of fixed $\mathrm{N}$ in soil following a crop of it makes it suitable as part of a soil fertility-building rotation with other crops such as corn (Zea mays; Stute and Posner, 1995; Huss-Danell et al., 2007). The $\mathrm{N}$ fixed by the legume can thus be used in the production of both energy- and proteinrich forages. The efficiency of use of $\mathrm{N}$ in protein-rich forages such as legume silages is often low, as a result of low concentrations of an energy source such as starch or water-soluble carbohydrates. Legume silages, such as red clover silage, are thus best fed mixed with another crop that can provide rumen-available energy to improve the capture of rumen-degradable protein. Corn silage offers this potential, with relatively high concentrations of starch being provided. Recent work investigating the use of red clover silage as the sole forage showed improvements in milk yields, compared with grass silage alone, largely through improvements in feed intake (Bertilsson and Murphy, 2003; Dewhurst et al., 2003; Al-Mabruk et al., 2004). However, Moorby et al. (2009), comparing mixtures of red clover and ryegrass silages, concluded that the optimum milk yields were achieved with a ratio of $66 \%$ red clover silage in the forage component of the diet. Similar results were found by Halmemies-Beauchet-Filleau et al. (2014), who found increased feed intakes and milk yields from feeding mixtures of grass and red clover, compared with them being fed alone, whereas Vanhatalo et al. (2009) 
found highest feed intakes by cows offered a 1:1 mixture of the 2 silages, but this did not translate to improvements in milk yields.

Most strains of Escherichia coli are commensal although the $\mathrm{O} 157$ strain is pathogenic in humans, with cattle being an important potential source of contamination of the food chain (Wells et al., 1991; Zhao et al., 1995). The cattle diet, and particularly its starch concentration, can significantly influence (reduce or increase) fecal shedding of $E$. coli, including the O157 strain (Callaway et al., 2009), whereas feeding of red clover hay has been shown to reduce the amount of $E$. coli in cattle rumen contents (Jacobson et al., 2002).

The hypothesis of this study was that mixing corn and red clover silages in varying proportions would improve the milk production from multiparous dairy cows and improve the efficiency of nitrogen utilization for milk production. It was also hypothesized that changing the ratio of red clover silage to corn silage may alter the fecal bacterial population, including E. coli O157 populations. The objectives of this experiment, therefore, were to investigate the effect of mixing red clover and corn silages at different ratios on feed intake, milk production, and whole-body $\mathrm{N}$ partitioning in dairy cows. Diet effects on gut pathogens were also investigated by studying feces.

\section{MATERIALS AND METHODS}

\section{Cows and Management}

All procedures used in this experiment were licensed and regulated by the UK Home Office under the Animals (Scientific Procedures) Act of 1986. The experiment used 24 multiparous Holstein-Friesian dairy cows, which had a mean weight of $623(\mathrm{SD}=51.4) \mathrm{kg}$ and $106(\mathrm{SD}=16.1)$ DIM at the start, in a $3 \times 3$ Latin square design with 8 replicated squares. Cows were kept in a freestall barn at all times, apart from a subset of 9 cows (3 per treatment) that were transferred to a metabolism unit for feed digestibility and $\mathrm{N}$ partitioning measurements for $10 \mathrm{~d}$ during each period of the experiment. Each experimental period lasted $28 \mathrm{~d}$, comprising an adaptation period (the first $21 \mathrm{~d}$ ) and a measurement period (the last $7 \mathrm{~d}$ ).

For 3 wk before the start of the experiment, all animals were fed a common covariate diet with ad libitum access (to ensure refusals of at least 0.1 of the quantity offered) to ryegrass silage and red clover (1:1 mix on a fresh matter basis) plus $4 \mathrm{~kg} / \mathrm{d}$ per cow of a standard purchased dairy concentrate feed (Dairy HC 18 pellets, Welsh Feed Producers, Carmarthen, UK). Cows were assigned to 1 of the 8 replicate Latin squares of 3 animals based on milk yield data collected over the week before the start of the experiment. Animals were ranked from highest to lowest milk yields, and the top 3 yielding cows were then allocated to square 1 , the next 3 yielders to square 2 , and so on with the lowest 3 yielding animals allocated to square 8 . Within each Latin square, animals were allocated at random to each of the 3 treatments. Cows in Latin squares 1, 4, and 7 were used for digestibility and whole-body $\mathrm{N}$ and $\mathrm{P}$ partitioning measurements.

Three dietary treatments were used in the experiment. These consisted of ad libitum access to 1 of 3 forages, comprising mixtures of corn and red clover silages, together with an allowance of $4 \mathrm{~kg}$ (fresh) of the same concentrate per day (offered as $2 \mathrm{~kg}$ at each milking, at approximately 0500 and $1500 \mathrm{~h}$ ). The forage treatments, prepared on a DM basis, were (1) R10, 90\% corn silage: $10 \%$ red clover silage; (2) R50, 50\%:50\% corn silage:red clover silage; and (3) R90, 10\%:90\% corn silage:red clover silage. The corn silage was not fed at $100 \%$ rates to avoid known potential issues associated with high starch concentrations, low protein concentrations, short fiber lengths. Although red clover silage fed as a sole forage is unlikely to cause problems, the R90 diet mix was prepared as the logical opposite to the R10 mix. The corn silage was prepared as a large bunker from a corn crop harvested with a self-propelled forage harvester fitted with a corn cracker, and using an inoculant (Sil-All Fireguard, Alltech UK, Stamford, UK; containing Lactobacillus plantarum, Enterococcus faecium, Lactobacillus salivarius, and Pediococcus pentosaceus) at manufacturer's recommended application rates $\left(10^{6} \mathrm{cfu} / \mathrm{g}\right.$ of fresh forage). The red clover silage was prepared as big round bales from second and third cuts of a monoculture sward of red clover (cv. Milvus), using an inoculant (Powerstart, Genus plc, Nantwich, Cheshire, UK; containing Lactobacillus plantarum) ensiling at the manufacturer's recommended rates $\left(10^{6} \mathrm{cfu} / \mathrm{g}\right.$ of fresh forage); the red clover crop was not chopped before baling. During the experiment, the red clover used was a mixture of the 2 silage cuts in a ratio of 2 bales first cut to 1 bale third cut. The concentrate feed had a declared ingredient list of wheat $(35 \%$ of the fresh matter), extracted rapeseed meal (17.5\%), corn meal (10\%), palm kernel expellers (10\%), molasses $(6 \%)$, field beans $(5.25 \%)$, soybean meal $(5 \%)$, wheatfeed $(4.05 \%)$, extracted sunflower meal $(3 \%)$, vegetable oil $(1.6 \%)$, and a mineral and vitamin mix (2.6\%).

The 3 corn and red clover mixes were prepared by thorough mixing in a Storti Labrador 120 mixer wagon fitted with a chopping auger (Ruston's Engineering Co. Ltd., Huntingdon, UK). Forage was dispensed into individual feed bins of forage intake control feeders (Insentec B.V., Marknesse, the Netherlands) to allow automatic recording of ad libitum feed intakes in the 
freestall barn, or into individual feed tubs (in the metabolism unit) as required, with cold storage $\left(4^{\circ} \mathrm{C}\right)$ if kept for more than $1 \mathrm{~d}$.

Between each experimental period, dietary treatments were switched from one to the other over the course of $4 \mathrm{~d}$ in steps of $25 \%$ difference between current and subsequent treatments. For example, changing from diet R10 (90\% corn silage:10\% red clover silage) to diet R90 (10\% corn silage:90\% red clover silage), cows were given diets in which the forage component was approximately 70, 50, and 30\% corn silage (the remainder being red clover) on the first, second, and third days at the start of the new period, and onto their final diet with $10 \%$ corn silage on the fourth day.

\section{Measurements and Sample Analysis}

Feed intakes and milk yields were recorded daily throughout the experiment, but only those data recorded during the last week of each period were used in statistical analyses. Samples of feed were collected daily and composited on a weekly basis for analysis, with storage at $-20{ }^{\circ} \mathrm{C}$. Concentrate samples (for all analyses) and silage samples (for freeze-DM, watersoluble carbohydrates, total $\mathrm{N}, \mathrm{pH}$, ammonia-N, VFA, and lactic acid) were submitted fresh (frozen). All other analyses were carried out using freeze-dried material; samples were dried to a constant weight to determine freeze-DM content. Silage $\mathrm{pH}$ was determined after water extraction using a Hydrus $400 \mathrm{pH}$ meter (Fisher Scientific UK, Loughborough, UK). Ammonia$\mathrm{N}$ concentration was determined enzymatically using glutamate dehydrogenase on a discrete analyzer (FP901M Chemistry Analyzer, Labsystems Oy, Helsinki, Finland; test kit No. 66-50, Sigma-Aldrich Co. Ltd., Poole, Dorset, UK). Silage lactate concentration was analyzed using L-lactate dehydrogenase (Boehringer Mannheim test kit no. 10139084 035, R-Biopharm Rhône Ltd., Glasgow, UK). Volatile fatty acids were determined by gas chromatography using a Chrompack CP 9002 chromatograph (CP-Sil 5CB column $10 \mathrm{~m}$ $\times 0.25 \mathrm{~mm}$ internal diameter, Varian Inc., Palo Alto, CA) following the method of Zhu et al. (1996). Sample OM concentration was determined by combustion at $550^{\circ} \mathrm{C}$ for $6 \mathrm{~h}$ in a muffle furnace. Silage residual watersoluble carbohydrate concentrations were determined spectrophotometrically using an auto-analyzer (SEAL Analytical Ltd., Southampton, UK) as described by Thomas (1977). Starch concentration was determined as the difference between the initial water-soluble carbohydrate concentration and water-soluble carbohydrate concentration (as glucose) determined after boiling in water and subsequent hydrolysis with amyloglucosidase
(Sigma-Aldrich Co. Ltd.). A coefficient of 0.9 was used as a factor for converting measured glucose release into the original starch concentration. Briefly, $0.4 \mathrm{~g}$ of sample was refluxed in $80 \mathrm{~mL}$ of deionized water for $30 \mathrm{~min}$, $20 \mathrm{~mL}$ of cold acetate buffer (comprising $40 \% \mathrm{vol} / \mathrm{vol} 1$ $M$ sodium acetate and $60 \% \mathrm{vol} / \mathrm{vol} 1 M$ acetic acid) was then added, and the mixture was allowed to cool for 20 min. This was then shaken for $1 \mathrm{~h}$ following addition of $10 \mathrm{~mL}$ of amyloglucosidase solution $(1 \mathrm{~g}$ in $100 \mathrm{~mL}$ of deionized water). This solution was then made up to $250 \mathrm{~mL}$, filtered, and a portion of the filtrate was analyzed for water-soluble carbohydrate concentration (Thomas, 1977). Total N concentration was determined using a Leco FP 428 nitrogen analyzer (Leco Corporation, St. Joseph, MI), and expressed as CP (total $\mathrm{N} \times 6.25)$ concentration. Total $\mathrm{P}$ concentrations were determined in samples following digestion in aqua regia for 2.5 to $3 \mathrm{~h}$ at $120^{\circ} \mathrm{C}$, with subsequent analysis of the extract by inductively coupled plasma atomic emission spectrometry (Liberty Series II, Varian Limited, Oxford, UK). Fiber analyses were carried out with the aid of Fibertec equipment (Tecator Ltd., Thornbury, Bristol, Somerset, UK). Neutral detergent fiber assayed with a heat stable amylase and, expressed inclusive of residual ash, was determined as described by Van Soest et al. (1991). Acid detergent fiber, expressed inclusive of residual ash, was analyzed according to the method of Van Soest and Wine (1967). Ether extract was determined using Soxtec System HT6 equipment (Perstorp Analytical Ltd., Berkshire, UK) using petroleum ether 40 to $60^{\circ} \mathrm{C}$ as the solvent.

Body weight was recorded on most days following morning milking by automatic weighing equipment when animals were in the freestall barn, and as they entered and left the metabolism unit for those that underwent the more detailed procedures. Body condition scores, assessed at the loin and tailhead (using a 0 to 5 scale; Mulvany, 1977), were recorded at the start of the experiment and at the end of each experimental period. Milk samples (approximately $200 \mathrm{~mL}$ in total per cow) were collected at each of 2 consecutive milkings at the end of each period on a Monday afternoon and Tuesday morning. Individual morning and evening milking samples of the same milk (approximately $50 \mathrm{~mL}$, with milk preservative) was sent for near infrared analysis of fat and protein (National Milk Records, Chippenham, $\mathrm{UK})$.

In addition to the above measurements, for those animals housed in the metabolism unit feed digestibility and $\mathrm{N}$ and $\mathrm{P}$ partitioning measurements were carried out during $6 \mathrm{~d}$ at the end of each experimental period as follows. Externally applied urine and feces separators were used to collect total outputs of excreta 
from the cows for $6 \mathrm{~d}$. Subsamples of feed, excreta, and milk were collected, kept fresh (chilled to $4^{\circ} \mathrm{C}$ ), and analyzed as previously described by Dewhurst et al. (2000) and Moorby et al. (2000, 2006). A further 100 $\mathrm{mL}$ of mixed composited urine were diluted with 400 $\mathrm{mL}$ of tap water and stored frozen for purine derivative analysis. Concentrations of urinary purine derivatives (allantoin and uric acid) were measured as described by Dewhurst et al. (1996). Nitrogen and P balances was calculated as the difference between total $\mathrm{N}$ and $\mathrm{P}$ intakes (in feed) and $\mathrm{N}$ and $\mathrm{P}$ outputs (in excreta and milk). Apparent whole-tract diet digestibility was also measured at these times as the difference in intake and output of DM, OM, N, and NDF, and these values were used to calculate intakes of digestible diet components for all cows on the appropriate treatments. Diet $\mathrm{ME}(\mathrm{Mcal} / \mathrm{kg})$ density was calculated as $3.7 \times$ digestibility of $\mathrm{OM}$ expressed as a proportion $(\mathrm{g} / \mathrm{g})$ of the DM (Agricultural and Food Research Council, 1993). In addition to feces samples required for digestibility and $\mathrm{N}$ and $\mathrm{P}$ partitioning measurements, a further 50 $\mathrm{mL}$ mixed subsample from each cow was collected and subsampled. This sample was kept fresh (chilled to $4^{\circ} \mathrm{C}$ ) for assessment of $E$. coli populations.

Feces E. coli populations (total and O157 strains) were enumerated under aseptic conditions as follows. A $30-\mathrm{g}$ subsample of feces was added to $270 \mathrm{~mL}$ of Ringer's solution in a Stomacher laboratory blender (Seward Ltd., Thetford, UK) bag, and blended for 3 min. A sterile pipette was used to transfer $1 \mathrm{~mL}$ of this initial inoculum into $9 \mathrm{~mL}$ of Ringer's solution to achieve a 1 in 10 dilution. A series of dilutions from $10^{-2}$ to $10^{-8}$ were prepared by repeated 1 in 10 dilutions for culturing. All dilutions were mixed using a vortex mixer for 5 to $10 \mathrm{~s}$ before plating. Sterile petri dishes, previously prepared with sorbitol MacConkey agar containing 5-bromo-4-chloro-3-indoxyl- $\beta$-D-glucuronide (BCIG; CM0981, Oxoid Ltd., Basingstoke, UK) with a cefixime tellurite selective supplement (SR0172E, Oxoid Ltd.) for the isolation of $E$. coli $\mathrm{O} 157$ (added at the rate of $1.25 \mathrm{mg}$ per $500 \mathrm{~mL}$ of agar solution), were spread with $100-\mu \mathrm{L}$ aliquots of the required inoculum dilutions. The petri dishes were inverted and incubated at $37^{\circ} \mathrm{C}$ for $24 \mathrm{~h}$. Total counts of E. coli colonies, and those of $E$. coli O157, were recorded on dilution plates with appropriate numbers of colonies, which were then back-calculated to give the number of colony-forming units per gram of feces.

\section{Statistical Analysis}

Data were analyzed using Genstat 11th Edition (VSN International Ltd., Hemel Hempstead, UK) by
ANOVA. Treatment effects were separated by polynomial contrasts into linear and other (nonlinear) effects (with 10, 50, and 90\% red clover silage in the diet). For analysis of silage composition data, a blocking structure of experimental period was used. For cow-derived data, a blocking structure of experimental period $\times$ (Latin square/cow) was used to control period and betweencow variation. Total E. coli enumeration data were log (base 10) transformed before analysis, but untransformed mean data are reported. Statistical significance was declared if $P<0.05$.

\section{RESULTS}

Of the 9 animals that were selected at the start of the experiment for more detailed feed digestibility and nutrient partitioning measurements, 3 (2 offered diet R90 and 1 offered diet R50) had to be returned to the main group for welfare reasons (they did not adapt to the urine and feces separation equipment) before the measurements could be completed in the first experimental period, and 2 were replaced with other cows for the second and third measurement periods. Within the full group of 24 cows, one cow developed mastitis and was culled during the third experimental period. Statistical analyses were carried out with missing values for data that could not be collected.

\section{Forage Composition}

Forage mixture $\mathrm{pH}$ and concentrations of $\mathrm{CP}$, watersoluble carbohydrates, NDF, and ADF increased as the proportion of red clover silage in the diet increased (Table 1). At the same time, the concentrations of starch, ether extract, and acetic and lactic acids decreased. Total diet concentrations of $\mathrm{CP}$ were approximately 12.4, 15.4, and $17.0 \%$ DM; NDF concentrations were approximately $38.5,41.6$, and $42.6 \% \mathrm{DM}$; and starch concentrations were $24.5,11.1$, and $6.9 \% \mathrm{DM}$, for diets R10, R50, and R90, respectively.

\section{Feed Intake, BW, and Milk Production}

Silage (and therefore total) DMI were similar for diets R10 and R90, with an increase of approximately $1 \mathrm{~kg}$ of $\mathrm{DM} / \mathrm{d}$ for those animals consuming the 1:1 mix of the 2 silages (diet R50; Table 2). Intakes of OM and NDF also followed this nonlinear trend, with intakes of OM higher on diet R10 than diet R90, and intakes of NDF being the reverse. Intakes of $\mathrm{CP}$, on the other hand, increased as the proportion of red clover silage in the diet increased, with a substantial concomitant decrease 
Table 1. Mean $(\mathrm{n}=6)$ compositions of the treatment mixtures of the corn and red clover (RC) silages fed during the experiment

\begin{tabular}{lcccc}
\hline & \multicolumn{3}{c}{ Treatment $^{1}$} \\
\cline { 2 - 3 } $\begin{array}{l}\text { Item, \% of DM unless } \\
\text { otherwise stated }\end{array}$ & $\mathrm{R} 10$ & $\mathrm{R} 50$ & $\mathrm{R} 90$ & Concentrate \\
\hline $\mathrm{NM}{ }^{2} \%$ & 33.8 & 41.9 & 51.6 & 88.3 \\
$\mathrm{OM}$ & 95.5 & 93.4 & 91.7 & 93.0 \\
$\mathrm{CP}$ & 10.7 & 14.4 & 16.3 & 20.3 \\
Ammonia-N & 0.20 & 0.22 & 0.22 & - \\
Water-soluble carbohydrates & 2.0 & 5.0 & 6.9 & 8.5 \\
Starch & 23.9 & 7.8 & 2.5 & 27.3 \\
NDF & 42.4 & 46.0 & 47.5 & 10.9 \\
ADF & 23.8 & 31.2 & 36.3 & - \\
Ether extract & 3.2 & 2.3 & 1.7 & 5.3 \\
Acid-hydrolysis ether extract & - & - & - & - \\
pH & 3.71 & 4.14 & 4.55 & - \\
Acetic acid & 1.37 & 1.09 & 0.78 & - \\
$n$-Butyric acid & & Below LOQ & \\
Lactic acid & 5.90 & 4.08 & 2.90 & - \\
Total P & 0.024 & 0.026 & 0.027 & 0.595 \\
\hline
\end{tabular}

${ }^{1}$ Treatment: $\mathrm{R} 10=90 \%$ corn silage: $10 \%$ red clover silage; $\mathrm{R} 50=50 \%$ corn silage: $50 \%$ red clover silage; $\mathrm{R} 90=$ 10\% corn silage: $90 \%$ red clover silage; all ratios on a DM basis.

${ }^{2}$ Determined by freeze drying.

${ }^{3}$ Limit of quantification $(0.07 \% \mathrm{DM})$.

in the intake of starch. With the exception of dietary $\mathrm{NDF}$, digestibilities of diet components measured all decreased linearly as the proportion of red clover silage in the diet increased.

There were small but statistically significant linear $(P<0.001)$ and nonlinear $(P<0.001)$ effects of dietary treatment on mean BW of the animals, with treatment means of 615,629 , and $630 \mathrm{~kg}$ [standard error of the differences $($ SED $)=3.3]$ for diets R10, R50, and R90, respectively. These were brought about by treatment effects over the course of the relatively short experimental periods, with BW change (calculated as the difference between mean BW at the start and end of each 4 -wk experimental period) of $-10.2,8.5$, and $11.0 \mathrm{~kg}$ $\left(\mathrm{SED}=3.97 ; P_{\text {nonlinear }}=0.03\right)$. However, no significant effect was found of dietary treatment on mean BCS

Table 2. Mean treatment effects on feed intakes, measured in all cows, and apparent whole-tract nutrient digestibility and ME density and intake, measured in a subset of cows

\begin{tabular}{|c|c|c|c|c|c|c|}
\hline \multirow[b]{2}{*}{ Item } & \multicolumn{3}{|c|}{ Treatment $^{1}$} & \multirow[b]{2}{*}{$\mathrm{SED}^{2}$} & \multicolumn{2}{|c|}{$P$-value of effect } \\
\hline & $\mathrm{R} 10$ & $\mathrm{R} 50$ & $\mathrm{R} 90$ & & Linear & Nonlinear \\
\hline \multicolumn{7}{|l|}{ Feed intake, kg/d } \\
\hline Forage DM & 16.1 & 17.0 & 16.0 & 0.32 & 0.74 & 0.001 \\
\hline Total DM & 19.6 & 20.5 & 19.5 & 0.32 & 0.74 & 0.001 \\
\hline $\mathrm{OM}$ & 18.6 & 19.2 & 17.9 & 0.30 & 0.02 & 0.002 \\
\hline $\mathrm{CP}$ & 2.43 & 3.16 & 3.32 & 0.047 & $<0.001$ & $<0.001$ \\
\hline $\mathrm{NDF}$ & 7.54 & 8.55 & 8.31 & 0.146 & $<0.001$ & $<0.001$ \\
\hline Starch & 4.80 & 2.29 & 1.35 & 0.071 & $<0.001$ & $<0.001$ \\
\hline \multicolumn{7}{|l|}{ Nutrient digestibility, \% } \\
\hline DM & 68.6 & 66.3 & 64.8 & 0.77 & $<0.001$ & 0.45 \\
\hline $\mathrm{OM}$ & 69.2 & 66.8 & 65.8 & 0.50 & $<0.001$ & 0.17 \\
\hline $\mathrm{NDF}$ & 46.2 & 56.1 & 60.8 & 1.51 & $<0.001$ & 0.09 \\
\hline $\mathrm{N}$ & 64.6 & 62.0 & 60.0 & 1.65 & 0.03 & 0.84 \\
\hline $\mathrm{P}$ & 50.3 & 54.1 & 45.7 & 1.16 & 0.007 & $<0.001$ \\
\hline $\mathrm{ME},{ }^{3} \mathrm{Mcal} / \mathrm{kg}$ of $\mathrm{DM}$ & 3.40 & 3.33 & 3.28 & 0.004 & $<0.001$ & 0.09 \\
\hline ME intake, Mcal/d & 70.0 & 70.5 & 65.6 & 1.67 & 0.04 & 0.12 \\
\hline
\end{tabular}

${ }^{1}$ Treatments: $\mathrm{R} 10=90 \%$ corn silage: $10 \%$ red clover silage; $\mathrm{R} 50=50 \%$ corn silage: $50 \%$ red clover silage; R90 $=10 \%$ corn silage: $90 \%$ red clover silage; all ratios on a DM basis

${ }^{2}$ Standard error of the differences of the means.

${ }^{3}$ Calculated as $3.7 \times$ digestibility of OM expressed as a proportion $(\mathrm{g} / \mathrm{g})$ of the DM. 
Table 3. Mean treatment effects of altering the dietary forage ratio of corn and red clover silages on milk yields and composition, and output of milk per unit of intake

\begin{tabular}{|c|c|c|c|c|c|c|}
\hline Item & \multicolumn{3}{|c|}{ Treatment $^{1}$} & $\mathrm{SED}^{2}$ & \multicolumn{2}{|c|}{$P$-value of effect } \\
\hline Fat & 3.67 & 3.75 & 3.89 & 0.140 & 0.12 & 0.82 \\
\hline Protein & 3.09 & 3.06 & 2.99 & 0.024 & $<0.001$ & 0.25 \\
\hline \multicolumn{7}{|l|}{ Milk constituent concentration, g/d } \\
\hline Milk yield/total DMI, kg/kg & 1.35 & 1.33 & 1.32 & 0.033 & 0.37 & 0.97 \\
\hline Milk yield/digestible DMI, $\mathrm{kg} / \mathrm{kg}$ & 1.97 & 2.01 & 2.03 & 0.049 & 0.18 & 0.76 \\
\hline
\end{tabular}

${ }^{1}$ Treatments: $\mathrm{R} 10=90 \%$ corn silage: $10 \%$ red clover silage; R50 $=50 \%$ corn silage: $50 \%$ red clover silage; R90 $=10 \%$ corn silage: $90 \%$ red clover silage; all ratios on a DM basis.

${ }^{2}$ Standard error of the differences of the means.

either at the loin (grand mean $=2.1 ; \mathrm{SED}=0.06$ ) or the tailhead (grand mean $=2.1 ; \mathrm{SED}=0.06$ ) or on change in BCS during each experimental period.

Milk yields followed DMI and were significantly higher (by 1.2 to $1.6 \mathrm{~kg} / \mathrm{d}$ ) from animals offered diet R50 compared with the other 2 diets (Table 3). Milk fat concentrations and yields were unaffected by dietary treatment, although milk protein concentrations declined linearly as the proportion of red clover silage in the diet increased. A significant nonlinear effect was found of diet on milk protein yields, with the highest yields coming from animals offered diet R50. The amount of milk produced per kilogram of DMI, and per kilogram of digestible DMI, was not different among diets.

\section{Whole-Body N and P Partitioning}

Output of $\mathrm{N}$ in feces and urine, as measured in a subset of the experimental cows, increased linearly as dietary $\mathrm{N}$ intake increased with increasing proportions of red clover silage in the diet (Table 4). Nonlinear effects on $\mathrm{N}$ intake and excretion in feces, and secretion into milk, followed DMI and milk yields respectively. The proportion of dietary $\mathrm{N}$ that was apparently secreted in milk decreased as the proportion of red clover silage in the diet increased, whereas the proportion of dietary $\mathrm{N}$ apparently excreted in urine increased. Similarly, P intakes and output in feces were affected by dietary treatment (Table 4), increasing with increasing proportions of red clover silage in the diet, whereas milk $\mathrm{P}$ output decreased marginally. There was a nonlinear effect of diet on $\mathrm{P}$ balance, with the highest amounts retained in animals offered diet R50. Partitioning of dietary P into feces was significantly nonlinearly affected by dietary treatment, being lowest on diet R50 and highest on diet
R90. Very little $\mathrm{P}$ was excreted in urine and there were apparently minimal treatment effects on the partitioning of dietary $\mathrm{P}$ into urine. Partitioning of dietary $\mathrm{P}$ into milk reduced significantly as the proportion of red clover in the diet increased.

\section{Output of E. coli, Urine, and Purine Derivatives}

There were no statistically significant differences among treatments in fecal outputs of E. coli O157 and all E. coli strains, with grand means (untransformed data) of $2.66 \times 10^{4}$ and $9.20 \times 10^{5} \mathrm{cfu} / \mathrm{g}$ of $\mathrm{DM}$, respectively. However, E. coli $\mathrm{O} 157$ was found only in 6 of the 22 samples analyzed, making it difficult to carry out a meaningful statistical analysis; 2 were from cows offered the R10 diet, 4 from cows offered the R50 diet, and the O157 strain was not found in the feces of any cows offered the R90 diet, even in those animals in which it had previously been found when they were consuming a different diet.

Urine outputs increased linearly as the proportion of red clover silage in the diet increased, so that the amount of urine produced by cows offered the R90 diet was $176 \%$ of that from cows offered the R10 diet (Table 4). Urinary excretion of allantoin increased linearly as the proportion of red clover silage in the diet increased, although excretion of uric acid decreased at the same time, so that total excretion of purine derivatives was only marginally affected by diet (Table 5 ). As a ratio of DMI, the urinary excretion of purine derivatives was significantly increased as the dietary intake of red clover silage increased, but as a ratio of $\mathrm{N}$ intake, this trend was reversed and was minimized on the R50 diet $\left(P_{\text {nonlinear }}<0.01\right)$. The output of creatinine in urine (expressed both on a $\mathrm{m} M / \mathrm{d}$ basis and in relation to $\mathrm{BW}$ ) was significantly affected by treatment (Table 5 ). The 
Table 4. Mean treatment effects of altering the dietary forage ratio of corn and red clover silages on $\mathrm{N}$ and $\mathrm{P}$ intakes, outputs and their apparent whole-body partitioning, and the quantities of urine produced by dairy cows ${ }^{1}$

\begin{tabular}{|c|c|c|c|c|c|c|}
\hline \multirow[b]{2}{*}{ Item } & \multicolumn{3}{|c|}{ Treatment $^{2}$} & \multirow[b]{2}{*}{$\mathrm{SED}^{3}$} & \multicolumn{2}{|c|}{$P$-value of effect } \\
\hline & $\mathrm{R} 10$ & $\mathrm{R} 50$ & $\mathrm{R} 90$ & & Linear & Nonlinear \\
\hline Feces & 138 & 201 & 223 & 7.2 & $<0.001$ & 0.02 \\
\hline Urine & 74 & 120 & 173 & 5.7 & $<0.001$ & 0.55 \\
\hline Milk & 128 & 145 & 137 & 4.8 & 0.12 & 0.02 \\
\hline Feces & 0.35 & 0.38 & 0.40 & 0.017 & 0.03 & 0.84 \\
\hline Urine & 0.19 & 0.23 & 0.31 & 0.013 & $<0.001$ & 0.14 \\
\hline Milk & 0.33 & 0.28 & 0.25 & 0.011 & $<0.001$ & 0.18 \\
\hline $\mathrm{P}$ intake, g P/d & 59 & 67 & 66 & 1.5 & 0.003 & 0.009 \\
\hline \multicolumn{7}{|l|}{$\mathrm{P}$ output, g P/d } \\
\hline Feces & 29 & 31 & 36 & 1.1 & 0.001 & 0.10 \\
\hline Urine & 0.15 & 0.16 & 0.15 & 0.025 & 0.99 & 0.50 \\
\hline Milk & 0.35 & 0.31 & 0.29 & 0.016 & 0.006 & 0.58 \\
\hline Urine output, $\mathrm{kg} / \mathrm{d}$ & 14.7 & 19.6 & 25.8 & 0.93 & $<0.001$ & 0.405 \\
\hline
\end{tabular}

${ }^{1}$ Measurements were carried out in a subset of the experimental cows $(\mathrm{n}=9)$.

${ }^{2}$ Treatments: $\mathrm{R} 10=90 \%$ corn silage: $10 \%$ red clover silage; R50 $=50 \%$ corn silage:50\% red clover silage; R90 $=10 \%$ corn silage:90\% red clover silage; all ratios on a DM basis.

${ }^{3}$ Standard error of the differences of the means.

highest rates of creatinine excretion were found on the R50 diet, with rates of excretion being the lowest from cows offered the R10 diet.

\section{DISCUSSION}

Corn silage is a forage typically characterized by low protein concentrations and high energy densities. Red clover silage, on the other hand, is a forage that is typically high in quickly degradable protein but relatively low in readily available energy (Dewhurst et al., 2009), making a mixture of the 2 forages appealing for improved nutrient utilization efficiency. In this study, as the proportion of red clover silage in the forage mixture increased, the $\mathrm{CP}$ concentration of the complete diet increased and the starch concentration decreased, clearly reflecting the different contributions of $\mathrm{CP}$ and starch from the red clover and corn silages.

Table 5. Mean treatment effects of altering the dietary forage ratio of corn and red clover silages on urinary excretion of purine derivatives (PD), and the ratio of PD to DM and $\mathrm{N}$ intakes, and daily excretion of creatinine by dairy cows ${ }^{1}$

\begin{tabular}{|c|c|c|c|c|c|c|}
\hline \multirow[b]{2}{*}{ Item } & \multicolumn{3}{|c|}{ Treatment $^{2}$} & \multirow[b]{2}{*}{$\mathrm{SED}^{3}$} & \multicolumn{2}{|c|}{$P$-value of effect } \\
\hline & $\mathrm{R} 10$ & $\mathrm{R} 50$ & $\mathrm{R} 90$ & & Linear & Nonlinear \\
\hline \multicolumn{7}{|l|}{ Purine derivatives, $\mathrm{m} M / \mathrm{d}$} \\
\hline Allantoin & 408 & 440 & 481 & 28.5 & 0.04 & 0.87 \\
\hline Uric acid & 16.0 & 13.2 & 11.3 & 1.27 & 0.01 & 0.70 \\
\hline Total PD & 424 & 454 & 491 & 29.4 & 0.06 & 0.86 \\
\hline $\mathrm{PD} / \mathrm{DMI}, \mathrm{m} M / \mathrm{kg}$ & 20.6 & 21.4 & 24.1 & 0.92 & 0.009 & 0.31 \\
\hline Creatinine, $\mathrm{mg} / \mathrm{kg}$ of $\mathrm{BW} / \mathrm{d}$ & 26.2 & 32.0 & 31.5 & 1.18 & 0.004 & 0.02 \\
\hline
\end{tabular}

${ }^{1}$ Measurements were carried out in a subset of the experimental cows $(\mathrm{n}=9)$.

${ }^{2}$ Treatments: R10 = 90\% corn silage: $10 \%$ red clover silage; R50 $=50 \%$ corn silage: $50 \%$ red clover silage; R90 $=10 \%$ corn silage: $90 \%$ red clover silage; all ratios on a DM basis.

${ }^{3}$ Standard error of the differences of the means. 


\section{Feed Intakes, Feed Digestibilities, and Milk Production}

The small increase in yields of milk and milk protein by cows fed the R50 diet reflect the small but significant increase in total DMI of feed on that treatment. However, the differences in milk yield between treatments are less than might be expected from the differences in the $\mathrm{CP}$ concentrations of the complete diets. The nonlinear effect of diet on milk production suggests that the balance of dietary energy CP supplies was most appropriate with a 1:1 mixture of corn and red clover silages in this study. The intake potential of red clover silage and corn silage is similar when they comprise the majority of the forage component of a diet (Benchaar et al., 2015), whereas intakes of diets based on legume and corn silages tend to be higher than those based on grass silages (Allen, 2000; Abrahamse et al., 2008; Dewhurst et al., 2010; Dewhurst, 2013). This may be related to the short fiber lengths in legume and corn silages compared with grass silage (Dewhurst et al., 2010) but this does not explain the small (approximately $1 \mathrm{~kg}$ of $\mathrm{DM} / \mathrm{d}$ ) but significant increase in feed intake of the 50:50 mixture of both silages. Many factors influence forage DMI in dairy cows including DM content, NDF concentration and degradability, and fiber particle length (Allen, 2000). The red clover silage in this study had a higher NDF concentration than the corn silage, but the overall diet NDF concentrations varied relatively little among the 3 diets. However, the digestibility of the red clover silage NDF was higher, perhaps from increased rates of rumen fiber fermentation (Dewhurst, 2013) or through an increase in diet CP concentration (Huhtanen et al., 2011), leading to increased whole-tract NDF digestibility by animals offered the diets containing red clover. This happened despite concomitant reductions in whole-tract digestibilities of DM and OM, although whole-tract digestibility values are not indicative of difference in rates of rumen fermentation or passage rate (Rode et al., 1985; Le Liboux and Peyraud, 1998). Therefore, the highest rates of DMI, and hence the highest milk yields, by animals offered the R50 diet might have resulted from an optimal balance between diet NDF concentrations and fiber fermentation rates in the rumen enabling faster passage rates (Wilson and Kennedy, 1996; Bertilsson and Murphy, 2003; Dewhurst, 2013). Increasing dietary CP concentration can increase DMI in dairy cows (Broderick, 2003; Cabrita et al., 2011), although this is not always found (e.g., Colmenero and Broderick, 2006). It may be hypothesized that increases in DMI in response to increased diet $\mathrm{CP}$ concentration may be partly driven by the interaction of energy-yielding nutrients and RDP, perhaps resulting in improved capture of RDP into microbial protein and reduced absorption of ammonia from the rumen. However, even when ammonia absorption is increased significantly, DMI can remain unaffected (Moorby and Theobald, 1999; Colmenero and Broderick, 2006).

Milk fat concentrations and yields were unaffected by dietary treatment. Similar results, although comparing feeding red clover silage with grass silage, were found by Al-Mabruk et al. (2004), whereas Vanhatalo et al. (2009) and Moorby et al. (2009) found a relative decrease in milk fat concentrations. Comparing red clover and corn silage mixtures, as in the present study, Dewhurst et al. (2010), found no effect of treatment on milk fat concentrations, but significant effects on milk fat yields. Even though protein intakes increased as the proportion of red clover silage in the diet increased, milk protein concentrations significantly decreased, although the absolute change in concentration was numerically small; again this effect has been found previously (Moorby et al., 2009; Vanhatalo et al., 2009). Milk protein yield increased as milk yield increased, such that the greatest protein yields were found from those cows offered the R50 diet, the 1:1 mix of red clover and corn silages. This is likely to be a result of a better balance of energy-yielding nutrients and protein on this diet than on either of the other 2 diets. Despite those cows offered the R90 diet consuming approximately $900 \mathrm{~g}$ of protein more per day than the R10 cows, this did not translate into any more milk protein. This was partly due to the reduction in whole-tract $\mathrm{N}$ digestibility as the proportion of red clover silage in the diet increased, leading to less digestible protein for absorption by the animal, and partly due to a concomitant reduction in the energy density of the diet; the highest intake of energy was achieved by cows consuming diet R50. It is possible that on all 3 treatment diets of the current study supplies of Met may have limited milk protein production, because Met is often limiting in corn silage-based diets (NRC, 2001) and supplies of Met from red clover silage have also found to be inadequate for optimal milk protein secretion (Vanhatalo et al., 2009).

\section{Purine Derivative Excretion and Nitrogen and Phosphorus Partitioning}

Purine derivative excretion in urine is a proxy for microbial protein outflow from the rumen (Chen et al., 1990; Vagnoni et al., 1997; Tas and Susenbeth, 2007), and assumes a constant ratio of $\mathrm{N}$ to purines in the microbial mass leaving the rumen. This assumption holds over a range of forage:concentrate ratios (Moorby et al., 2006), and when different forages (including red clover) are fed (Merry et al., 2006). In this study, increases 
in the daily urinary excretion of purine derivatives (particularly allantoin) as the proportion of red clover silage in the diet increased suggest an increase in the microbial protein flow from the rumen, which was likely driven by increases in $\mathrm{N}$ intake. Apparent efficiency of microbial protein production in the rumen (purine excretion per unit $\mathrm{N}$ intake) was highest in cows offered diet R10, indicating better capture of rumen available $\mathrm{N}$ into microbial $\mathrm{N}$ with the higher concentrations of starch present in this diet.

Total collection of urine output for estimating microbial protein production using purine derivatives is not always possible, and creatinine is commonly used as a volume marker (Chen et al., 1995; Valadares et al., 1999; Chizzotti et al., 2008). Creatinine excretion is related to body protein turnover and $\mathrm{BW}$, and although some studies have found it to be unaffected by diet (e.g., Valadares et al., 1999; Moorby et al., 2006; Chizzotti et al., 2008), other studies have found dietary influences on creatinine excretion from cattle (Faichney et al., 1995; Gonda et al., 1996), making the use of creatinine of less value than using total urine collections for estimating purine derivative excretion (Shingfield and Offer, 1998). The rates of creatinine excretion we found were similar to other published values (e.g., Shingfield and Offer, 1998; Valadares et al., 1999; Moorby et al., 2006), and indicate that without knowledge of the actual volumes of urine produced, the estimates of purine derivative excretion would have been very different in this study. Treatment differences observed in this study may have been related to changes in BW, which were negative over the course of each experimental 4-wk period for cows offered the R10 diet, which also had the lowest rates of creatinine excretion, and positive for cows offered diets R50 and R90. Urine volume is closely related to the consumption of $\mathrm{Na}, \mathrm{K}$, and $\mathrm{N}$ (Bannink et al., 1999) when water intake is not limited, and it is likely that the increasing output of urine as the red clover content of the diets increased in the present study was a result of the increasing intake of $\mathrm{N}$ from those diets.

Protein that is degraded in the rumen and not incorporated into microbial protein is absorbed from the rumen, converted to urea in the liver, and largely excreted in urine. As the proportion of red clover in the diet increased, large increases in $\mathrm{N}$ intake led to concomitant increases in $\mathrm{N}$ excretion in feces and urine. The difference in average daily $\mathrm{N}$ excretion between cows consuming diets R10 and R90 (184 g/d) was greater than the difference in mean $\mathrm{N}$ intake $(162 \mathrm{~g} / \mathrm{d})$. A small reduction in diet $\mathrm{N}$ digestibility with red clover silage meant that proportionally more dietary $\mathrm{N}$ was excreted in feces, but substantially more $\mathrm{N}$ was excreted in urine at the same time. Most of the urinary
$\mathrm{N}$ was lost as a result of inefficient capture of rumen degradable protein in the rumen (Gonda and Lindberg, 1994) as less starch was available from reducing proportions of corn silage to enable this (Kebreab et al., 2001). Overall, although increasing the proportion of red clover in the diet increased the supply of dietary $\mathrm{N}$, which in turn led to apparent increases in rumen microbial protein production, the efficiency of use of the dietary $\mathrm{N}$ decreased with reduced intakes of starch from corn silage, and more dietary $\mathrm{N}$ was excreted in urine. Ultimately, the diet that resulted in the highest milk protein yields (R50) was not the most efficient in terms of milk protein production from dietary N (R10), and was probably not the absolute best ratio of the red clover and corn silages to optimize the use of the crops by dairy cows, which would be determined by a balance between $\mathrm{N}$ supply, microbial $\mathrm{N}$ production, and use of absorbed protein by the animal for milk production.

Excretion of $\mathrm{P}$ in urine was very low, as expected (Manston and Vagg, 1970; Morse et al., 1992). The forage components of the complete diets provided relatively small amounts of dietary P (less than one-third of the total amount) compared with what was supplied in the concentrate supplement fed at the same rate for all 3 diets, leading to small differences in $\mathrm{P}$ intake. Dietary P concentrations (mean of $0.31 \% \mathrm{DM}$ ) were slightly lower than recommended by NRC, 2001 (i.e., 0.32 to $0.37 \% \mathrm{DM}$ ), but secretion of $\mathrm{P}$ in milk was similar among treatments and $\mathrm{P}$ balance was positive in all animals, suggesting the supply of $\mathrm{P}$ was adequate. Despite this there were significant effects of dietary treatment on apparent whole-tract digestibility of $\mathrm{P}$ and on subsequent apparent partitioning of $\mathrm{P}$ between feces, milk, and body retention. This may be related to changes in the rumen microbial population resulting from the difference in the forage components of the diets because $\mathrm{P}$ digestion is influenced by microbial phytase activity, with absorption from the gut by the small intestine, and recycling of $\mathrm{P}$ back into the rumen via saliva (Hill et al., 2008). Previous work found little difference in $\mathrm{P}$ digestibility or whole-body $\mathrm{P}$ partitioning when feeding red clover and ryegrass silages to dry dairy cows (Moorby et al., 2008), but whole-tract P digestibility was much lower than in the current study, possibly because no supplemental concentrates were fed to the dry cows, and therefore no supplemental inorganic $\mathrm{P}$ (as part of a mineral premix in a concentrate) was supplied.

\section{Fecal Output of E. coli}

Escherichia coli $\mathrm{O} 157$ is a major cause of foodborne illness in humans (Scallan et al., 2011; Tam et al., 2012), and fecal material from cattle is a source of food con- 
tamination. Fecal populations of E. coli are influenced by grain in the diet of dairy cattle, with higher shedding from cattle fed high concentrate diets compared with those on high forage diets because of proliferation of the bacteria enabled by starch fermentation in the hindgut (Callaway et al., 2003). Despite large differences in starch intake between the diets, no apparent differences were found in fecal outputs of E. coli O157 or of all E. coli strains in this study. The starch in the diets of the present study originated from corn silage (not corn grain), which tends to be more digestible in the rumen than grain starch and therefore results in less flow of starch to the small intestine (Knowlton et al., 1998). As a consequence, large intestine fermentation of starch in the current study may have been too small to have had a significant effect on populations and fecal shedding of $E$. coli.

\section{CONCLUSIONS}

This study demonstrated the value of red clover silage to offer good feeding value for use as a high protein forage for milk production from dairy cows and confirmed the hypothesis that equal mixtures of corn and red clover silages offered the optimum diet in terms of feed intake potential and milk production from dairy cows, with the 2 forages ensuring a balance of proteinand energy-yielding nutrients from the mixture. Purine derivative excretion data indicate that microbial protein production in the rumen was greatest with the highest proportion of red clover in the diet, but this did not result in the greatest yields of milk or milk protein, perhaps because of a limitation in the supply of energy-yielding nutrients in this diet. No significant effect of forage treatment on total fecal populations of $E$. coli was detected.

\section{ACKNOWLEDGMENTS}

The authors gratefully acknowledge funding from the European Community financial participation under the Sixth Framework Programme for Research, Technological Development and Demonstration Activities, for the Integrated Project QualityLowInputFood, FP6-FOODCT-2003-506358. We thank W. J. Fisher, D. W. R. Davies, M. Leyland, J. K. S. Tweed, E. L. Bakewell, M. B. Scott, and D. Jones of the Institute of Biological, Environmental and Rural Sciences, for their technical assistance, and R. Sanderson for statistical advice.

\section{REFERENCES}

Abrahamse, P. A., B. Vlaeminck, S. Tamminga, and J. Dijkstra. 2008. The effect of silage and concentrate type on intake behavior, ru- men function, and milk production in dairy cows in early and late lactation. J. Dairy Sci. 91:4778-4792.

Agricultural and Food Research Council. 1993. Energy and protein requirements of ruminants. An advisory manual prepared by the AFRC Technical Committee on Responses to Nutrients. CAB International, Wallingford, UK.

Al-Mabruk, R. M., N. F. G. Beck, and R. J. Dewhurst. 2004. Effects of silage species and supplemental vitamin $\mathrm{E}$ on the oxidative stability in milk. J. Dairy Sci. 87:406-412.

Allen, M. S. 2000. Effects of diet on short-term regulation of feed intake by lactating dairy cattle. J. Dairy Sci. 83:1598-1624.

Bannink, A., H. Valk, and A. M. VanVuuren. 1999. Intake and excretion of sodium, potassium, and nitrogen and the effects on urine production by lactating dairy cows. J. Dairy Sci. 82:1008-1018.

Benchaar, C., F. Hassanat, R. Martineau, and R. Gervais. 2015. Linseed oil supplementation to dairy cows fed diets based on red clover silage or corn silage: Effects on methane production, rumen fermentation, nutrient digestibility, $\mathrm{N}$ balance, and milk production. J. Dairy Sci. 98:7993-8008.

Bertilsson, J., and M. Murphy. 2003. Effects of feeding clover silages on feed intake, milk production and digestion in dairy cows. Grass Forage Sci. 58:309-322.

Broderick, G. A. 2003. Effects of varying dietary protein and energy levels on the production of lactating dairy cows. J. Dairy Sci. 86:1370-1381.

Cabrita, A. R. J., R. J. Dewhurst, D. S. P. Melo, J. M. Moorby, and A. J. M. Fonseca. 2011. Effects of dietary protein concentration and balance of absorbable amino acids on productive responses of dairy cows fed corn silage-based diets. J. Dairy Sci. 94:4647-4656.

Callaway, T. R., M. A. Carr, T. S. Edrington, R. C. Anderson, and D. J. Nisbet. 2009. Diet, Escherichia coli O157:H7, and cattle: A review after 10 years. Curr. Issues Mol. Biol. 11:67-79.

Callaway, T. R., R. O. Elder, J. E. Keen, R. C. Anderson, and D. J. Nisbet. 2003. Forage feeding to reduce preharvest Escherichia coli populations in cattle, a review. J. Dairy Sci. 86:852-860.

Chen, X. B., F. D. D. Hovell, E. R. Ørskov, and D. S. Brown. 1990. Excretion of purine derivatives by ruminants: effects of exogenous nucleic acid supply in purine excretion by sheep. Br. J. Nutr. 63:131-142.

Chen, X. B., A. T. Mejia, D. J. Kyle, and E. R. Orskov. 1995. Evaluation of the use of the purine derivative-creatinine ratio in spot urine and plasma samples as an index of microbial protein supply in ruminants - Studies in sheep. J. Agric. Sci. 125:137-143.

Chizzotti, M. L., S. C. Valadares Filho, R. F. D. Valadares, F. H. M. Chizzotti, and L. O. Tedeschi. 2008. Determination of creatinine excretion and evaluation of spot urine sampling in Holstein cattle. Livest. Sci. 113:218-225.

Colmenero, J. J. O., and G. A. Broderick. 2006. Effect of dietary crude protein concentration on milk production and nitrogen utilization in lactating dairy cows. J. Dairy Sci. 89:1704-1712.

Dewhurst, R. J. 2013. Milk production from silage: Comparison of grass, legume and maize silages and their mixtures. Agric. Food Sci. 22:57-69.

Dewhurst, R. J., L. J. Davies, and E. J. Kim. 2010. Effects of mixtures of red clover and maize silages on the partitioning of dietary nitrogen between milk and urine by dairy cows. Animal 4:732-738.

Dewhurst, R. J., L. Delaby, A. Moloney, T. Boland, and E. Lewis. 2009. Nutritive value of forage legumes used for grazing and silage. Ir. J. Agric. Food Res. 48:167-187.

Dewhurst, R. J., W. J. Fisher, J. K. S. Tweed, and R. J. Wilkins. 2003. Comparison of grass and legume silages for milk production. 1. Production responses with different levels of concentrate. J. Dairy Sci. 86:2598-2611.

Dewhurst, R. J., A. M. Mitton, N. W. Offer, and C. Thomas. 1996. Effects of the composition of grass silages on milk production and nitrogen utilization by dairy cows. Anim. Sci. 62:25-34.

Dewhurst, R. J., J. M. Moorby, M. S. Dhanoa, R. T. Evans, and W. J. Fisher. 2000. Effects of altering energy and protein supply to dairy cows during the dry period. 1. Intake, body condition, and milk production. J. Dairy Sci. 83:1782-1794. 
Faichney, G. J., R. J. Welch, and G. H. Brown. 1995. Prediction of the excretion of allantoin and total purine derivatives by sheep from the creatinine coefficients. J. Agric. Sci. 125:425-428.

Gonda, H. L., M. Emanuelson, and M. Murphy. 1996. The effect of roughage to concentrate ratio in the diet on nitrogen and purine metabolism in dairy cows. Anim. Feed Sci. Technol. 64:27-42.

Gonda, H. L., and J. E. Lindberg. 1994. Evaluation of dietary nitrogen utilization in dairy cows based on urea concentrations in blood, urine and milk, and on urinary concentration of purine derivatives. Acta Agric. Scand. 44:236-245.

Halmemies-Beauchet-Filleau, A., A. Vanhatalo, V. Toivonen, T. Heikkilä, M. R. F. Lee, and K. J. Shingfield. 2014. Effect of replacing grass silage with red clover silage on nutrient digestion, nitrogen metabolism, and milk fat composition in lactating cows fed diets containing a 60:40 forage-to-concentrate ratio. J. Dairy Sci. 97:3761-3776.

Hill, S. R., K. F. Knowlton, E. Kebreab, J. France, and M. D. Hanigan. 2008. A model of phosphorus digestion and metabolism in the lactating dairy cow. J. Dairy Sci. 91:2021-2032.

Huhtanen, P., M. Hetta, and C. Swensson. 2011. Evaluation of canola meal as a protein supplement for dairy cows: A review and a metaanalysis. Can. J. Anim. Sci. 91:529-543.

Huss-Danell, K., E. Chaia, and G. Carlsson. 2007. N-2 fixation and nitrogen allocation to above and below ground plant parts in red clover-grasslands. Plant Soil 299:215-226.

Jacobson, L. H., T. A. Nagle, N. G. Gregory, R. G. Bell, G. Le Roux, and J. M. Haines. 2002. Effect of feeding pasture-finished cattle different conserved forages on Escherichia coli in the rumen and faeces. Meat Sci. 62:93-106.

Kebreab, E., J. France, D. E. Beever, and A. R. Castillo. 2001. Nitrogen pollution by dairy cows and its mitigation by dietary manipulation. Nutr. Cycl. Agroecosyst. 60:275-285.

Knowlton, K. F., B. P. Glenn, and R. A. Erdman. 1998. Performance, ruminal fermentation, and site of starch digestion in early lactation cows fed corn grain harvested and processed differently. J. Dairy Sci. 81:1972-1984.

Le Liboux, S., and J. L. Peyraud. 1998. Effect of forage particle size and intake level on fermentation patterns and sites and extent of digestion in dairy cows fed mixed diets. Anim. Feed Sci. Technol. $73: 131-150$.

Manston, R., and M. J. Vagg. 1970. Urinary phosphate excretion in dairy cow. J. Agric. Sci. 74:161.

Merry, R. J., M. R. F. Lee, D. R. Davies, R. J. Dewhurst, J. M. Moorby, N. D. Scollan, and M. K. Theodorou. 2006. Effects of high-sugar ryegrass silage and mixtures with red clover silage on ruminant digestion. 1 . In vitro and in vivo studies of nitrogen utilization. J. Anim. Sci. 84:3049-3060.

Moorby, J. M., R. J. Dewhurst, R. T. Evans, and J. L. Danelon. 2006. Effects of dairy cow diet forage proportion on duodenal nutrient supply and urinary purine derivative excretion. J. Dairy Sci. 89:3552-3562

Moorby, J. M., R. J. Dewhurst, J. K. S. Tweed, M. S. Dhanoa, and N. F. G. Beck. 2000. Effects of altering the energy and protein supply to dairy cows during the dry period. 2. Metabolic and hormonal responses. J. Dairy Sci. 83:1795-1805.

Moorby, J. M., M. R. F. Lee, D. R. Davies, E. J. Kim, G. R. Nute, N. M. Ellis, and N. D. Scollan. 2009. Assessment of dietary ratios of red clover and grass silages on milk production and milk quality in dairy cows. J. Dairy Sci. 92:1148-1160.

Moorby, J. M., P. H. Robinson, W. J. Fisher, and R. T. Evans. 2008. Comparison of red clover and ryegrass silage for dry cows and influence on subsequent lactation performance. J. Dairy Sci. 91:3501-3511.

Moorby, J. M., and V. J. Theobald. 1999. The effect of duodenal ammonia infusions on milk production and nitrogen balance of the dairy cow. J. Dairy Sci. 82:2440-2442.
Morse, D., H. H. Head, C. J. Wilcox, H. H. Van Horn, C. D. Hissem, and B. Harris Jr.. 1992. Effects of concentration of dietary phosphorus on amount and route of excretion. J. Dairy Sci. 75:30393049.

Mulvany, P. 1977. Dairy Cow Condition Scoring. National Institute for Research in Dairying, Reading, UK.

NRC. 2001. Nutrient Requirements of Dairy Cattle. 7th rev. ed. National Academy Press, Washington, DC.

Rode, L. M., D. C. Weakley, and L. D. Satter. 1985. Effect of forage amount and particle size in diets of lactating dairy cows on site of digestion and microbial protein synthesis. Can. J. Anim. Sci. 65:101-111.

Scallan, E., R. M. Hoekstra, F. J. Angulo, R. V. Tauxe, M.-A. Widdowson, S. L. Roy, J. L. Jones, and P. M. Griffin. 2011. Foodborne illness acquired in the United States-Major pathogens. Emerg. Infect. Dis. 17:7-15.

Shingfield, K. J., and N. W. Offer. 1998. Evaluation of the spot urine sampling technique to assess urinary purine derivative excretion in lactating dairy cows. Anim. Sci. 66:557-568.

Stute, J. K., and J. L. Posner. 1995. Legume cover crops as a nitrogensource for corn in an oat corn rotation. J. Prod. Agric. 8:385-390.

Tam, C. C., L. C. Rodrigues, L. Viviani, J. P. Dodds, M. R. Evans, P. R. Hunter, J. J. Gray, L. H. Letley, G. Rait, D. S. Tompkins, and S. J. O'Brien. 2012. Longitudinal study of infectious intestinal disease in the UK (IID2 study): Incidence in the community and presenting to general practice. Gut 61:69-77.

Tas, B. M., and A. Susenbeth. 2007. Urinary purine derivates excretion as an indicator of in vivo microbial $\mathrm{N}$ flow in cattle: A review. Livest. Sci. 111:181-192.

Thomas, T. A. 1977. An automated procedure for the determination of soluble carbohydrates in herbage. J. Sci. Food Agric. 28:639-642.

Vagnoni, D. B., G. A. Broderick, M. K. Clayton, and R. D. Hatfield 1997. Excretion of purine derivatives by Holstein cows abomasally infused with incremental amounts of purines. J. Dairy Sci. 80:1695-1702.

Valadares, R. F. D., G. A. Broderick, S. C. Valadares, and M. K. Clayton. 1999. Effect of replacing alfalfa silage with high moisture corn on ruminal protein synthesis estimated from excretion of total purine derivatives. J. Dairy Sci. 82:2686-2696.

Van Soest, P. J., J. B. Robertson, and B. A. Lewis. 1991. Methods for dietary fiber, neutral detergent fiber, and nonstarch polysaccharides in relation to animal nutrition. J. Dairy Sci. 74:3583-3597.

Van Soest, P. J., and R. H. Wine. 1967. Use of detergent in the analysis of fibrous feeds. IV. Determination of plant cell wall constituents. J. AOAC 50:50-55.

Vanhatalo, A., K. Kuoppala, S. Ahvenjarvi, and M. Rinne. 2009. Effects of feeding grass or red clover silage cut at two maturity stages in dairy cows. 1. Nitrogen metabolism and supply of amino acids. J. Dairy Sci. 92:5620-5633.

Wells, J. G., L. D. Shipman, K. D. Greene, E. G. Sowers, J. H. Green, D. N. Cameron, F. P. Downes, M. L. Martin, P. M. Griffin, S. M Ostroff, M. E. Potter, R. V. Tauxe, and I. K. Wachsmuth. 1991. Isolation of Escherichia coli serotype O157:H7 and other shigalike-toxin-producing E. coli from dairy cattle. J. Clin. Microbiol. 29:985-989.

Wilson, J. R., and P. M. Kennedy. 1996. Plant and animal constraints to voluntary feed intake associated with fibre characteristics and particle breakdown and passage in ruminants. Aust. J. Agric. Res. 47:199-225.

Zhao, T., M. P. Doyle, J. Shere, and L. Garber. 1995. Prevalence of enterohemorrhagic Escherichia coli O157-H7 in a survey of dairy herds. Appl. Environ. Microbiol. 61:1290-1293.

Zhu, W.-Y., M. K. Theodorou, A. C. Longland, B. B. Nielsen, J. Dijkstra, and A. P. J. Trinci. 1996. Growth and survival of anaerobic fungi in batch and continuous-flow cultures. Anaerobe 2:29-37. 